\title{
各種植物性凝集素のニワトリ赤血球に対する 凝集性および溶血性に関する研究
}

\author{
水谷 誠・梅沢英彦・會就茂実
}

日坐研小㴊次支社，山梨紧小浴沢町 409-16

(1983. 4. 18 受付)

\begin{abstract}
要 約 44 種のマメ科植物を含む159種の植物の抽出液について,ブラックミノルカ種, 白色レク ホーン種, フアヨウミ種特よびニューヘンプシャー種を含を10 羽のニワトりの赤血球に対する凝集性 および溶血性を試験した．その結果，抽出液は次の 6 群に区分された．第 1 群；すべての個体の赤血球 を凝集も溶血もしなかったもの78種，第 2 群；すべての個体の赤血球を凝集し，溶血しなかったもの 40 種，第 3 群; すべての個体の赤血球を凝集せず，溶血したもの11 種，第 4 群; すべての個体の赤血球 を凝集し，かつ容血したもの 3 種，第 5 群；一部の個体の赤血球を凝集するが，他の個体の赤血球は凝 集せず，すべての個体の赤血球を溶血しなかったもの 24 種，第 6 群；一部の個体の赤血球を凝集する が，他の個体の赤血球は凝集せず，すべての個体の赤血球を容血しだすの 3 種，ニワトリの個体間差を 識別しえた第 5 群拉よび第 6 群については試験個体数をらやして凝集性を調査した結果，凝集性の違い から次の 4 群に区分されたａ 群；従来の動物血液型之同様，盽雄の別なく陽性・陰性個体を区分した わの.これに属するむのはラッカセイを含む 15 種であった，b 群；Hi $(P h)$ 凝集原と反応していると思 れたもの．これに属するものはエンドウを含む 8 種であった．C群； a, b 両群の性質をるっているむ

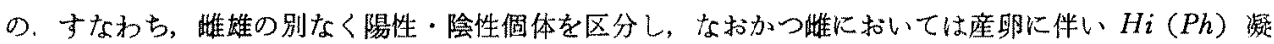
集原之異なる凝集原の出現炕より凝集性が变化するすの．これに属するものはジャガイモ，チニーリッ プの 2 種であった。d 群; Hi $(P h)$ 凝集原あるいはC群の凝集原とも異なる㠜集原が産卵に伴い出現し， 凝集性が変化するるの．これに属するものは二ラ1種であった。
\end{abstract}

日畜会報，54(9)：525-534，1983

ニワトリの血液型に閏する研究は主として同種兔疫抗 血清により行われ，これまでに少なくとも常染色体上に 位置する12のシステムが明らかにされている ニワトリの主要組織適合性遺伝子座でするる Bシステム に関しては，種々の近交系を用いて詳細な分析がなさ れ，マウスに拈ける $H-2$ 座位，七トに拈けるHLA 座 位などと類似の遗伝子配列が報告されている6-9).

同種兔疫抗血清はニワトリの個体間差を最もよく識別 するが，異なる研究室で作製された抗血清間の同定がむ 亏゙かしといら久点がある. 在疫抗血清以外の凝集法に よる血液型分類には，ウイルス性凝集素(VHA)，動物 の細胞抽よび組織から得られる凝集素 (THA) および植 物性凝集菜 (lectin あるいは PHA) などが用いられて いる ${ }^{10}$. これらの凝集素に関しては，異なる研究室で作 製されたものでも同定は簡単で，しかも同一のものを一 度に多量に作製しらるといら利点を有している。これら 日蓄会報，54(9)：525-534
の点でVHA，THA 峁よびレクチンにより識別される

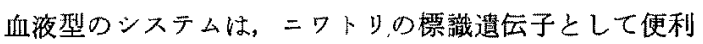
なるのと思われる。しかし，これらの凝集素を用いて明 らかにされたニワトり血液型システムの数は少なく， $\mathrm{VHA}^{11-13)}$ ，THA ${ }^{14}$ 执よびレクチン ${ }^{15-19)}$ に扰いて2〜3の システムが報告されているのみである。な㧊、エンドウ レクチンにおいて見出された $H i(P h)$ システムは，遗 伝的特性とともにその出現にはエストロジェンの存在が 必須であるという與味深い凝集原であった。

著者らはニワトリの血液型に関する標識遭伝子の数を らやす目的で，44䅜のマメ科植物を含む159種の植物か ら得た抽出液について，ニワトリ赤血球に対する凝集性 および溶血性を検討したので報告する。

\section{材料および方法}

抽出液作製浩；44種のマメ科植物を含む 159 種の植物 1983 


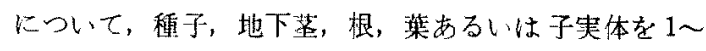
2 昼夜生理的食塩水に漫した後, 等量 (w/v) の生理的

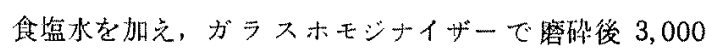
$\mathrm{rpm}$ で 10 分間遠心分離し，上潍を睬取し $56^{\circ} \mathrm{C} 30$ 分閒 加熱した. その後再び $3,000 \mathrm{rpm}$ で 10 分閏遠心分離し, 得られた上清を使用までー20“Cて湅結保存した。な祘， フスハラガス、エコ゚キなよのよらに硬くてガラスホを

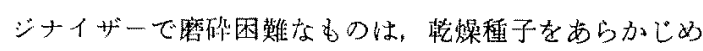
乳バチで厒，生理的食塩水に1〜2冝夜浸した後, ガ ラスホモジナイザーで磨砕した。また，ナがイモいい ては上述の方法で作製した抽出液は粘液状を呈し，㠜集 反応が観察しにくいので, 1 2 昼夜 $-20^{\circ} \mathrm{C} て ゙$ 凍結後融解 したるのを，ラッカセイ和よびサワグルミについてはェ チルエーテルで脱脂後のむのを用いた。

ニワトリ；当研究所において維持しているブラックミ ノル力種, 白色レダー・ン種, フアヨウミ種执よびニュ

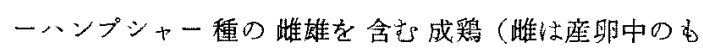
の）10羽を用いた。な括，第 2 次試驗に打いては，標識 造伝子として使用可能と思われたレクチンの凝集性学検 討与るため上述の品種から作出した 6 系統の雃婎（雌は 應䀧のるの）各 10 羽以上を用いた。

採血法; 採血はすべて翼下静脈より行った。

赤血球凝集反応法; プラスチック嶈凝集板を用いた。 生理的食塩水儿上り原液掊数希釈(最䅂肴釈 128 倍) し た抽出液 $0.1 \mathrm{ml} に$ にニトリ赤血球 $2 \%$ 浮遊液 $0.1 \mathrm{~m} l$ を 加室温に静组し， 1 時間および 2 時間後に凝集像を観 察し、結果を判定した。 その後, 再度浮避させ $4^{\circ} \mathrm{CK} 1$ 亘夜放圈し，寒冷凝集素の有無を観察した。記録は原液 で㠜集したすのを䡃性とし、2 倍希积本で㠜集したすの を㠜集価 2，最終希秎 128 倍まで凝集したものを凝集価

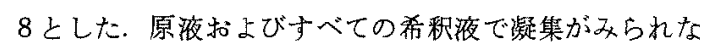
かったものを陌性とした，溶血については，原液で溶血 したものを溶血とした。

\section{結果および考察}

I. 第 1 次試験（抽出液の分類）

159 種の植物の楥子，地下芏，根，葉あるいは子実体 から抽出液を調製し，4品種のニワトリの崔雄を含む 10 羽の赤血球に対する反忙性を試験した。武䮖した植物は それらの抽出液の赤血球凝集性执上び溶血性に上って次 の6群に区分された（表 1 ).

第 1 群, 寸べての個体の赤血球老凝集当溶血もしなか ったもの、ソテッ科：ソテッイチョウ科：イチョウ， プナ科：クリ，クルミ科：サワグルミ，クワ科：アサ， タデ科: ソバ,フカザ科：ホウレンソウ，ヤマゴボウ科：
ヤマゴホウクスノキ科：クスノキ，モクレン科：コブ シ,フウチョウソウ科: クレオメ、アブラナ科：サント ウナ, コマッナ，ノザワナ，カブラ，八クサイ， 八ッカ ダイコン, ミカン科: キンカン, カラタチ, ッリフネン ウ科：ツリフネソウ，ホウセンカ，ニシキギ科：ニシキ ギ，モクセイ科：ライラック，七ルガ才科：サッマイモ， ナス科：ナス：シソ科：サルピア，バラ科：ビワ，スモ モ,ゴマ科：ゴマ，マメ科：アズキ：シュウハチササゲ， サンジャクササゲ，オジギソウ，カワラケッメイ，レッ ドクローバー,レンゲソウ，セイヨウハナズオウ，ネム ノキ,クズ,ダイズ, リミ、ッルマメ, エニシダ, ル ピナス, ミズ科: アオキ,ウコギ科：キョウセンニンシ ソ, セり科: ニンジン, パリ，アカネ科: コーヒー, ウリ科：キュウリ，力ポチャ，キク科：ヒマワリ，キク

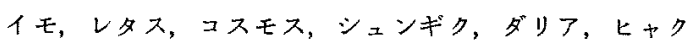
ニチソウ，コボウオモダカ科：クワイ，イネ科：コム ギ, 八トムギ, トウモロコシ，サトイモ科：マムシグサ, ニリ科, ニンニタ,ナルコンリ，才モト，アスパラガス， ヒガンバナ科：ハマオモト，アマリリス，ヤマノイモ科: ナガイモ，アヤメ科：クロッカス，ショウガ科：ショウ ガ, ゼンマイ科: ゼンマイ、シメジ科：シイタケ，モエ ギタケ科：ナメコキクラダ科：キクラゲ、トクサ科: スギナ,の78種であった。

第 2 群，すべての個体の赤血球を凝集し，溶血しなか ったもの. イチイ科：カヤ、マッ科：アカマッ,ヤナギ 科: ヤマネコヤナギ，カバノキ科：シラカバ，ブナ科: コナラ,クメギ,アラカッ, クスノキ科：丁ボガド，フ ブラナ科：ダィコン，ウルシ科：マンゴー, ツッジ科： レソダッッジ、モクせイ科：ヒイラギ，ナス科チョウ センアサガオ、マメ科：キヌサヤインゲン、ツルナシイ ンゲン,トーロクマメ,キントキマメ, シモササゲ, ウ ズラマメ、サンドインゲン, シャクゴスンインゲン， ト ップクロップ, トラマメ、ミッムネ，アカハナササゲ， シロハナササゲ, マスターピー, シササゲ, アカハナフ シマメ,ヤマフジ, ナタマメ(Con A), エンジュ, ア カパナ科: マッヨイグサ, ウリ科: ユリガオ, シラタマ ニリ，七ガンバ,科：スイ七ン, アヤメ科: アヤメ, 力 ソナ科：カンナ，シメジ科：ホンシタジ，八ラタケ科： ックリタケ，の40種であった。

第 3 群，すべてての個体の赤血球を凝集せずに溶血し たもの. ツルムラサキ科：ソルムラサキ、アケビ科：ア タビ、ツバキ科: サザンカ，サクラソウ科：シクラメン、 エゴノキ科: エゴノキ，ヒルガオ科：アサガオ，トベラ 科: トべラ, ウコギ科：タラ、ュリ科：ムスカリ，七ヤ シンス,フリージア、の11種であった。 


$$
\text { ニワトリ赤血球 }
$$

Table 1. List of plants grouped by agglutinabilities of their lectins to the red blood cells of chickens (Family name in capitals)

\begin{tabular}{|c|c|c|}
\hline Botanical name & Japanese name & Group No. \\
\hline \multicolumn{3}{|l|}{$C Y A D A C E A E$} \\
\hline Cycas revoluta & Sotetsu & I \\
\hline \multicolumn{3}{|l|}{ GINGOACEAE } \\
\hline Ginkgo biloba & Icho & I \\
\hline \multicolumn{3}{|l|}{$T A X A C E A E$} \\
\hline Torreya nucifera & Kaya & III \\
\hline \multicolumn{3}{|l|}{$P I N A C E A E$} \\
\hline Pinus densiflora*** & Akamatsu & II \\
\hline \multicolumn{3}{|l|}{$S A L I C A C E A E$} \\
\hline Salix bakko**** & Yamanekoyanagi & II \\
\hline \multicolumn{3}{|l|}{$B E T U L A C E A E$} \\
\hline Retula platyphylla*** & Shirakaba & II \\
\hline \multicolumn{3}{|l|}{$F A G A C E A E$} \\
\hline Castanea crenata & Kuri & I \\
\hline Quercus crispula & Kunugi & II \\
\hline " glauca & Arakashi & II \\
\hline$/ 1 \quad$ serrata & Konara & II \\
\hline \multicolumn{3}{|l|}{$J U G L A N D A C E A E$} \\
\hline Pterocarya rhoifolia & Sawagurumi & I \\
\hline \multicolumn{3}{|l|}{$C A N N A B I N A C E A E$} \\
\hline Cannabis sativa & Asa & I \\
\hline \multicolumn{3}{|l|}{ POLYGONACEAE } \\
\hline Fagopyrum esculentum & Soba & I \\
\hline \multicolumn{3}{|l|}{ CHENOPODIACEAE } \\
\hline Spinacia oleracea & Horenso & I \\
\hline \multicolumn{3}{|l|}{ PHYTOLACCACEAE } \\
\hline Phytolacca esculenta & Yamagobo & I \\
\hline \multicolumn{3}{|l|}{$B A S E L L A C E A E$} \\
\hline Basella rubra & Tsurumurasaki & III \\
\hline \multicolumn{3}{|l|}{$L A D I Z A B A L A C E A E$} \\
\hline Akebia quinata & Akebi & III \\
\hline \multicolumn{3}{|l|}{$L A U R A C E A E$} \\
\hline Persea americana & Abogado & II \\
\hline Cinnamomum camphora & Kusunoki & I \\
\hline \multicolumn{3}{|l|}{$M A G N O L I A C E A E$} \\
\hline Magnolia kobus*** & Kobushi & I \\
\hline
\end{tabular}

Explanation of the table. I: did not agglutinate and did not hemolyze the red blood cells of all the chickens tested. II: agglutinated but not hemolyze the red blood cells of all the chickens tested. III: did not agglutinate but did hemolyze the red blood cells of all the chickens tested. IV: both agglutinated and hemolyzed the red blood cells of all the chickens tested. V: agglutinated the red blood cells of some chickens, but did not agglutinate the remainder and did not hemolyze the red blood cells of all the chickens tested. VI: agglutinated the red blood cells of some chickens, but did not agglutinate the remainder and did hemolyze the red blood cells of all the chickens tested. *: lectins prepared from stem. **: lectins prepared from root. ***: lectins prepared from leaf. ****: lectins prepared from fruit body. No mark: lectins prepared from seed. 
水谷・梅沢 - 居益

Table 1-2. (cont'd) (Explanations are on the first page of the table)

\begin{tabular}{|c|c|c|}
\hline Botanical name & Japanese name & Group No. \\
\hline \multicolumn{3}{|l|}{$C A P P A R I D A C E A E$} \\
\hline Cleome spinosa & Cleome & I \\
\hline \multicolumn{3}{|l|}{ CRUCIFERAE } \\
\hline Brassica juncea & Santona & $\mathrm{I}$ \\
\hline$" \quad$ rapa var pervidis & Komatsuna & I \\
\hline$" \prime \quad r a p a$ & Nozawana & I \\
\hline$"$ rapa & Kabura & I \\
\hline " pekinensis & Hakusai & I \\
\hline Raphanus sativus & Daikon & II \\
\hline$\| 1$ & Hatsukadaikon & I \\
\hline \multicolumn{3}{|l|}{$R U T A C E A E$} \\
\hline Fortunella japonica & Kinkan & I \\
\hline Ponicirus trifoliata & Karatachi & $\mathrm{I}$ \\
\hline \multicolumn{3}{|l|}{$T H E A C E A E$} \\
\hline Camellia Sasanqua & Sazanka & III \\
\hline \multicolumn{3}{|l|}{$B A L S A M I N A C E A E$} \\
\hline Impatiens balsamina & Hosenka & I \\
\hline$"$ Textori & Tsurifuneso & I \\
\hline \multicolumn{3}{|l|}{$A N A C A R D I A C E A E$} \\
\hline Mangifera indica & Mango & II \\
\hline \multicolumn{3}{|l|}{$M U L V A C E A E$} \\
\hline Abermoschus esculentus & Okura & $\mathrm{V}$ \\
\hline \multicolumn{3}{|l|}{$C A R I C A C E A E$} \\
\hline Carica papaya & Papaiya & $\mathrm{V}$ \\
\hline \multicolumn{3}{|l|}{ CELAST RACEAE } \\
\hline Euonymus alata & Nishikigi & I \\
\hline \multicolumn{3}{|l|}{$E R I C A C F A E$} \\
\hline Rhododendron japonicum & Rengetsutsuji & II \\
\hline \multicolumn{3}{|l|}{ PRIMULACEAE } \\
\hline Cyclamen** & Cyclamen & III \\
\hline \multicolumn{3}{|l|}{$O L E A C E A E$} \\
\hline Osmanthus ilicifolius & Hiiragi & II \\
\hline \multicolumn{3}{|l|}{$S T Y R A C A C E A E$} \\
\hline Styrax japonica & Egonoki & III \\
\hline \multicolumn{3}{|l|}{$O L E A C E A E$} \\
\hline Syringa reticulata & Lilac & $\mathrm{I}$ \\
\hline \multicolumn{3}{|l|}{ CONVOLVULOIDEAE } \\
\hline Ipomoea batatus** & Satsumaimo & I \\
\hline Pharbitis Nil & Asagao & III \\
\hline \multicolumn{3}{|l|}{ SOLANACEAE } \\
\hline Solanum tuberosum* & Jagaimo & $\mathrm{V}$ \\
\hline$" \quad$ melongena & Nasu & I \\
\hline Datura metel & Chosenasagao & II \\
\hline \multicolumn{3}{|l|}{ STACHYOIDEAE } \\
\hline Salvia & Salvia & I \\
\hline \multicolumn{3}{|l|}{$R O S A C E A E$} \\
\hline Eriobotrya japonica & Biwa & I \\
\hline
\end{tabular}




$$
\text { ニワトリ亦犋球 }
$$

Table $1-3$. (cont'd) (Explanations are on the first page of the table)

\begin{tabular}{|c|c|c|}
\hline Botanical name & Japanese name & Group No. \\
\hline Prunus salicina & Sumomo & I \\
\hline \multicolumn{3}{|l|}{$P E D A L I A C E A E$} \\
\hline Sesanum indicum & Goma & I \\
\hline \multicolumn{3}{|l|}{ PITTOSPORACEAE } \\
\hline Pittosporum Tobira & Tobera & III \\
\hline \multicolumn{3}{|l|}{$P L A T A N A C E A E$} \\
\hline Platanus orientalis & Suzukakenoki & $\mathrm{V}$ \\
\hline \multicolumn{3}{|l|}{ LEGUMINOSAE } \\
\hline Phaseolus vulgaris & Kinusayaingen & II \\
\hline 11 & Tsurunashiingen & II \\
\hline$\prime \prime$ & Torokumame & II \\
\hline$\prime \prime$ & Kintokimame & II \\
\hline$\prime \prime$ & Shimosasage & II \\
\hline$\prime \prime$ & Uzuramame & II \\
\hline$\prime \prime$ & Sandoingen & II \\
\hline$\prime \prime$ & Shakugosuningen & II \\
\hline 11 & Top crop & II \\
\hline$\prime \prime$ & Toramame & II \\
\hline$\prime \prime$ & Mitsumune & II \\
\hline$\prime \prime$ & Akahanasasage & II \\
\hline$\prime \prime$ & Shirohanasasage & II \\
\hline$\prime \prime$ & Master pea & II \\
\hline$\prime \prime$ & Shisasage & II \\
\hline Phaseolus angularis & Azuki & I \\
\hline Pisum sativum & Mitoriendo & $\mathrm{V}$ \\
\hline$\prime \prime \prime \prime$ & Kinusayaendo & V \\
\hline Vicia sativa & Yahazuendo & $\mathrm{V}$ \\
\hline Vicia faba & Soramame & $\mathrm{V}$ \\
\hline Dolichos lablab & Akahanafujimame & III \\
\hline Vigna sinensis & Juhachisasage & I \\
\hline$\prime \prime \prime$ & Sanjakusasage & I \\
\hline Wisteria brachybotrys & Yamafuji & III \\
\hline Canavalia gladiata & Natamame (Con A) & II \\
\hline Robinia pseudo-acacia & Niseakasia & V \\
\hline Acacia & Akasia & $\mathrm{V}$ \\
\hline Lathyrus odoratus & Sweet pea & $\mathrm{V}$ \\
\hline Mimosa pudica & Ojigiso & I \\
\hline Cassia nomame & Kawaraketsumei & I \\
\hline Trifolium pratense & Red clover & I \\
\hline Astralus sinicus & Rengeso & I \\
\hline Cercis & Seiyohanazuo & I \\
\hline Albizzia Julibrissin & Nemunoki & I \\
\hline Lespedera bicolor & Yamahagi & $\mathrm{V}$ \\
\hline Desmodium racemosum & Nusubitohagi & $\mathrm{V}$ \\
\hline Pueraria Thunbergiana & Kuzu & I \\
\hline Glycine Max & Daizu & I \\
\hline " 11 & Norimi & I \\
\hline
\end{tabular}


水谷・梅沢 - 倉益

Table 1-4. (cont'd) (Explanations are on the first page of the table)

\begin{tabular}{|c|c|c|}
\hline Botanical name & Japanese name & Group No. \\
\hline Glycine Soja & Tsurumame & $\mathrm{I}$ \\
\hline Arachis hypogaea & Rakkasei & $\mathrm{V}$ \\
\hline Sophora japonica & Enju & II \\
\hline Cytisus scoparius & Enishida & I \\
\hline Lupinus luteus & Lupinus & I \\
\hline \multicolumn{3}{|l|}{$O N A G R A C E A E$} \\
\hline Oenothera odorata & Matsuyoigusa & II \\
\hline \multicolumn{3}{|l|}{ CORNACEAE } \\
\hline Cormus controversa*** & Mizuki & $\mathrm{V}$ \\
\hline Aucuba japonica & Aoki & I \\
\hline \multicolumn{3}{|l|}{$A R A L I A C E A E$} \\
\hline Panox schin-seng** & Chosenninjin & I \\
\hline Aralia elata*** & Tara & III \\
\hline \multicolumn{3}{|l|}{ UMBELLIFERAE } \\
\hline Daucus carota & Ninjin & I \\
\hline Petroselinum sativum & Parsley & I \\
\hline \multicolumn{3}{|l|}{$R U B I A C E A E$} \\
\hline Coffea arabica & Coffee & I \\
\hline \multicolumn{3}{|l|}{ CUCURBITACEAE } \\
\hline Cucumis sativa & Kyuri & I \\
\hline Cucurbita moschata & Kabocha & I \\
\hline Lagenaria leucantha & Yugao & II \\
\hline \multicolumn{3}{|l|}{ COMPOSIT AE } \\
\hline Helianthus annuus & Himawari & I \\
\hline "I tuberosus* & Kikuimo & I \\
\hline Lactuca Scariola & Lettuce & I \\
\hline Cosmos bipinnatus & Cosmos & I \\
\hline Chrysanthenum coronarum & Shungiku & I \\
\hline Dahlia pinnata** & Dahlia & I \\
\hline Zinnia elegans & Hyakunichiso & I \\
\hline Arctium Lappa & Gobo & I \\
\hline \multicolumn{3}{|l|}{$A L I S M A C E A E$} \\
\hline Sagittaria trifolia** & Kuwai & I \\
\hline \multicolumn{3}{|l|}{ FESTUCOIDEAE } \\
\hline Triticum aestivum & Komugi & I \\
\hline \multicolumn{3}{|l|}{ PANICOIDEAE } \\
\hline Coix Ma-yuen & Hatomugi & I \\
\hline \multicolumn{3}{|l|}{ GRAMINEAE } \\
\hline Zea mays & Tomorokoshi & I \\
\hline \multicolumn{3}{|l|}{$A R A C E A E$} \\
\hline Colocasia esculenta" ${ }^{\circ}$ & Satoimo & $\mathrm{V}$ \\
\hline$" 1 " \quad *$ & Yatsugashira & $\mathrm{V}$ \\
\hline Arisaema serratum* & Mamushigusa & I \\
\hline \multicolumn{3}{|l|}{$L I L I A C E A E$} \\
\hline Muscari* & Muscari & III \\
\hline Tulipa Generiana* & Tulip & $\mathrm{V}$ \\
\hline
\end{tabular}




$$
\text { ニワトリ亦衈球 }
$$

Table 1-5. (cont'd) (Explanations are on the first page of the table)

\begin{tabular}{|c|c|c|}
\hline Botanical name & Japanese name & Group No. \\
\hline Convallaria majalis & Suzuran & $\mathrm{VI}$ \\
\hline Allium sativum* & Ninniku & 1 \\
\hline " fistulosum & Negi & $\mathrm{V}$ \\
\hline$\prime \prime \quad$ tuberosum & Nira & $\mathrm{V}$ \\
\hline Polygonatum falcatum & Narukoyuri & I \\
\hline Lilium speciosum* & Shiratamayuri & II \\
\hline Hosta undulata & Giboushi & $\mathrm{IV}$ \\
\hline Hyacinthus orientalis* & Hyacinth & III \\
\hline Rohdea japonica & Omoto & $\mathrm{I}$ \\
\hline Asparagus officinalis & Asparagus & I \\
\hline \multicolumn{3}{|l|}{$A M A R Y L I D A C E A E$} \\
\hline Crinum asiaticum & Hamaomoto & $\mathrm{I}$ \\
\hline Narcissus Tazetta* & Suisen & II \\
\hline Amaryllis & Amaryllis & $\mathrm{I}$ \\
\hline \multicolumn{3}{|l|}{ DIOSCOREACEAE } \\
\hline Dioscorea batatas* & Nagaimo & I \\
\hline \multicolumn{3}{|l|}{$I R I D A C E A E$} \\
\hline Iris Nertshinskia* & Ayame & III \\
\hline Gladiolus gandavensis* & Gladiolus & IV \\
\hline Freesia $*$ & Freesia & III \\
\hline Crocus* & Crocus & I \\
\hline Crocus sativus* & Saffron & IV \\
\hline \multicolumn{3}{|l|}{ ZINGIBERACEAE } \\
\hline Zingiber officinale ${ }^{* *}$ & Shoga & I \\
\hline \multicolumn{3}{|l|}{$C A N N A C E A E$} \\
\hline Canna india* & Canna & II \\
\hline \multicolumn{3}{|l|}{ PTERIDACEAE } \\
\hline Pteridium aquilinum*** & Warabi & $\mathrm{V}$ \\
\hline \multicolumn{3}{|l|}{$O S M U N D A C E A E$} \\
\hline Osmunda japonica*** & Zenmai & I \\
\hline \multicolumn{3}{|l|}{ TRICHOLOMAT ACEAE } \\
\hline Clitocybe clavipes**** & Hoteishimeji & $\mathrm{VI}$ \\
\hline Lentinus edodes**** & Shiitake & $\mathrm{I}$ \\
\hline Flammulina velutipes $* * * * * *$ & Enokitake & $\mathrm{VI}$ \\
\hline Plourotus ostreatus**** & Hiratake & $\mathrm{V}$ \\
\hline Lyophyllum aggregatum**** & Honshimeji & II \\
\hline \multicolumn{3}{|l|}{ STROPHARIACEAE } \\
\hline Naematoloma sublateritium**** & Kuritake & $\mathrm{V}$ \\
\hline Pholiota nameko**** & Nameko & I \\
\hline "lenta**** & Shironametsumutake & $\mathrm{V}$ \\
\hline \multicolumn{3}{|l|}{$A G A R I C A E A E$} \\
\hline Agaricus bisporus***** & Tsukuritake & II \\
\hline \multicolumn{3}{|l|}{ AURICULARIACEAE } \\
\hline Auricularia auricula-judae $e^{* * * *}$ & Kikurage & I \\
\hline \multicolumn{3}{|c|}{ EQUISET ACEAE } \\
\hline Equisetum arvense*** & Sugina & I \\
\hline
\end{tabular}


Table 2. The agglutinability of the red blood cells from various chicken strains with various lectins

\begin{tabular}{|c|c|c|c|c|c|c|c|c|c|c|c|c|}
\hline \multirow{3}{*}{ Breed } & \multirow{3}{*}{ Strain } & \multirow{3}{*}{ Sex } & \multicolumn{10}{|c|}{ Lectins } \\
\hline & & & \multicolumn{2}{|c|}{ Peanut } & \multirow{2}{*}{$\begin{array}{c}\text { Garden } \\
+\end{array}$} & \multirow{2}{*}{$\begin{array}{l}\text { Pea } \\
-\end{array}$} & \multicolumn{2}{|c|}{ Tulip } & \multicolumn{2}{|c|}{ Potato } & \multicolumn{2}{|c|}{$\begin{array}{c}\text { Allium } \\
\text { tuberosum }\end{array}$} \\
\hline & & & + & - & & & + & - & + & - & + & - \\
\hline \multirow{2}{*}{ Black Minorca } & \multirow{2}{*}{$\mathrm{BM}-\mathrm{C}$} & $\delta$ & 5 & 11 & 0 & 50 & 1 & 36 & 25 & 0 & \multirow{2}{*}{\multicolumn{2}{|c|}{ N T }} \\
\hline & & 우 & 13 & 11 & 50 & 0 & 0 & 19 & 30 & 0 & & \\
\hline \multirow{2}{*}{ White Leghorn } & \multirow{2}{*}{ WL-GM } & $\hat{\jmath}$ & 15 & 7 & 0 & 50 & 0 & 25 & 0 & 18 & 0 & 26 \\
\hline & & 우 & 18 & 11 & 0 & 50 & 0 & 40 & 34 & 0 & 0 & 28 \\
\hline \multirow{2}{*}{$" 1$} & \multirow{2}{*}{ WL-15 } & $\hat{\sigma}$ & 2 & 10 & 0 & 20 & 18 & 0 & 0 & 24 & \multirow{2}{*}{\multicolumn{2}{|c|}{ N T }} \\
\hline & & 웅 & 2 & 10 & 0 & 20 & 20 & 0 & 0 & 28 & & \\
\hline \multirow{2}{*}{ Fayoumi } & \multirow{2}{*}{ PNP } & $\widehat{o}$ & 50 & 0 & 0 & 30 & 0 & 24 & 22 & 0 & 0 & 21 \\
\hline & & 웅 & 50 & 0 & 0 & 30 & 1 & 29 & 24 & 0 & 0 & 40 \\
\hline \multirow{2}{*}{$\|$} & \multirow{2}{*}{ GSP } & $\delta$ & 0 & 50 & 0 & 30 & 6 & 17 & 17 & 0 & 0 & 44 \\
\hline & & 우 & 0 & 50 & 0 & 30 & 0 & 28 & 16 & 0 & 2 & 40 \\
\hline \multirow{2}{*}{ New Hampshire } & \multirow{2}{*}{$\mathrm{NH}-412$} & $\delta$ & 11 & 15 & 0 & 11 & 6 & 14 & 20 & 0 & 0 & 24 \\
\hline & & 8 & 35 & 20 & 1 & 22 & 12 & 14 & 27 & 0 & 35 & 62 \\
\hline
\end{tabular}

Females are laying status. NT: Not tested.

第 4 群，すべての個体の赤血球を凝集し，かつ溶血し たbの.ユリ科：キボウン、アヤメ科：グラジオラス， サフランの3 種であった。

第 5 群. 一部の㮯体の亦血球を凝集するが，他の個体 の赤血球は凝集せず，ナべての個体の赤血球を溶血しな かったもの. アオイ科:オクラ，パハイヤ科：パパイヤ， ナス科：ジャガイと，スズ力タノキ科：スズカケ非， マメ科: ミトリエンドウ, キヌサヤエンドウ, ヤ八ズエ ソドウ，ソラマメ、ニセアカシア，アカシア，スィート

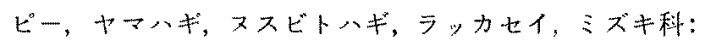
ミズキ,サトイモ科，サトイモ，ヤッガシラ、ニり科: チューリップ, ネギ,ニラ, ワラビ科：ワラビ, シかジ 科：ヒラタケ，モエギタケ科：クリタケ，シロナメッム タケの 24 種であった。

第 6 群，一部の赤血渄を疑集するが，他の個体の赤血 球は凝集せず，す心゙ての個体の赤血球を溶血したもの. ユり科: スズランシ人ジ科：ホテイシィジエノキタ ケ,の3種であった.

II. 第 2 次試験（第 5 群扰よび第 6 群の各抽出液の 㠜集珄に関小る陚験)

ニロトリの個体間差を識別しえた第 5 群および第 6 群 に属するレタチンについて, 試験個体数をらやして赤血 球凝集性を調查した結果，これらのレクチンは凝集性の 違いから次の4群に区分された。各群を代表するラッカ セイ，エンドウ，チニーリップ，ジャガイ毛执よび= の各レクチンの種々の系統のニワトリ赤血球に対する凝
集性を表 2 に示した.

a. 徒来の動物血液型上同樣, 雌雄の別广く晹性 - 陰 性個体を区分したもの。これに属するものはオクラ，バ ハイヤ，スズカケノキ，二セアカシア，アカシア，ヤマ

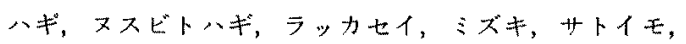
ヤツガシラ、ネギ, ワラビ, ヒラタケ、スズラン, ホテ イシメジの16種であった。しかしこれらのレクチン のらち陽性個体に対する㠜集価が 4 以上のbのはラッカ セイレクチンのみであり，他のレタチンの陽性個体に対 する凝集俩は2 -3であり，標識遗后子として使用可能 と思われるものはラッカセイレタチンのみと思わ扎た。 な怙，ワラビレクチンも利用しらると思われたが，ワラ ビの個体差のためか作製ロットにより凝集性が異なった ため，現段階では有用性が低いと判定した。

b. $H_{i}(P h)$ 凝集原と反応していると思われたもの. これに属するむのはミトリェンドウ，キスサヤエンド ウ，ヤハズエンドウ，ソラマィ， スィートピー, クリ夕 ケ、シロナメツムタケ、エノキタケの8種であり，これ らのレクチンは反応ハターンが $\mathrm{Hi}$ 凝集素と同じで, 特

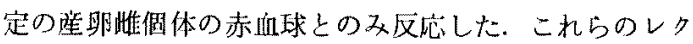
チンKより检出される $H i(P h)$ 凝集原は常染色体上の 㳊一優性頲伝子により支配され，エストロジェンの存在 で出現する ${ }^{15-17) ， こ の た め ， H i ~}(P h)$ 㠜集原は産卵扥 においての灭検出可能であるが，本レクチンの凝集価は 6〜7と高く，標識遗伝子としての有用性は高い.

c. a 群とb群の两性質をるっているもの.すなわち, 
倠雄の別なく陽性個体と陰性個体を区分し，なおかつ䧳 に扣いては産卵に伴い $\mathrm{Hi}(P h)$ 凝集原と異なる凝集原 の出現により凝策性が変化するすの。これに属するもの はジャガイモ、チューリップの 2 種であった。

ジャガイモレクチンと反広する凝集原は 2 種類存在し た. 1 種（ $S t_{1}$ 凝集原と仮称，凝集価 5〜6) は性成熟 前において雌雄の別をとわず 存在するもの（BM-C， PNP, GSP, NH-412 の各系統に存在), 他の1種 (St 2 と 仮称，凝集価 5 6) は $\mathrm{Hi}(\mathrm{Ph})$ 凝集原と同しく 1 部の 産畉堆に括いての名存する(WL-GM 系在存在) bの であるが，これら雨凝集原はジャガイモレクチンの亦血 球による吸收試呀では分離不可能であった。このため， $S t_{2}$ 凝集原の存在の有無を確認することは, $S t_{1}$ 凝集原が

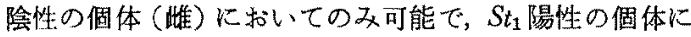
お汀る $S t_{2}$ の有無の判定は交配実験の結果によらねばな らない.

チェーリップレクチンと反応する凝集原 (WL-15系に 存在，凝集価 5〜6) b性成熟前のニワトリで堆雄の別な く存在した。しかしここの凝集原を有する唯に打いては 産卵に伴い凝集価 5 6が 1 2 に低下する現象がみられ た、この現象はニホンウズラにおいて報告された“ $S b "$ 凝集原の産卵時消失現象 ${ }^{20)}$ 之似て拐方興味深い。

これら 2 種のレクチンにより検出される凝集原む漂識 遗伝子としての有用性は高いと思和れた。

d. $H i(P h)$ 凝集原および C群の凝集原とも異なる凝 集原が産卵に伴い出現するため，凝集性が変化するすの (NH-412k存在)，こ机に属するものは二ラ1種であっ た。この㠜集原（凝集価 4 5) む標識遺后子として有用 と思われた<smiles>[3H][Mg]</smiles>

1) Briles, W. E., World's Poultry Sci, J., 16: 223-
242. 1960.

2) Gilmour, D. G., Brit. Poultry Sci., 1: 75-100. 1960.

3) Briles, W. E., Ann. NY Acad. Sci., 97: 173183. 1962 .

4) Gilmour, D. G., Ann. NY Acad. Sci, 97: 166172. 1962.

5) Briles, W. E. and L.B. Crittenden, Poultry Sci., 50: 1558. 1971.

6) Hála, K., M. Vilhelmova and J. Hartmanova, Immunogenetics, 3: 97-103. 1976.

7) Pink, J. R. L., W. Droege, K. HẦa, V. C. Migglano and A. Ziegler, Immunogenetics, 5: 203-216. 1977.

8) Evert, D. L., D. G. Gilmour, W. E. Briles and M. D. CoOper, Immunogenetics, 10: 169-174. 1980.

9) Chanh, T.C., A. A. Benedict and H. Abplanalp, J. Exptl. Med., 144: 555-561. 1966.

10）藤尾芳久，SABCO J., 1：21-27， 1965.

11) Nagler, F. P., Med. J. Aust, 1: 281, 1942.

12) Clark, E. and F.P. O. Nagler, Australian J. Exp. Biol. Med. Sci, 21: 103-106. 1943.

13) Salminen, A., Nature, 194: 1301. 1962.

14) Fuıro, Y., Biken J., 6: 155. 1963.

15) Scheinberg, S. L. and R.P. Reckel, Poultry Sci., 40: 689-698. 1961 a.

16) Scheinberg, S. L. and R. P. Reckel, Poultry Sci, 40: 795-807. 1961 b.

17) Scheningerg, S. L. and R. P. Reckel, Ann. NY Acad. Sci., 97: 194-204. 1962.

18）水谷 誠・滕尾芳久，日嫘会報，42：401-408. 1971.

19) Fujio, Y. and M. Mizutani, Japan J. Genetics, 50: 394-401, 1975.

20）水谷 誠・梅沢英彦・倉益茂実，日畜会報，48： 227-234. 1977 


\section{Studies on Agglutinability and Hemolytic \\ Activity of Various Lectins on Red \\ Blood Cells in Chickens}

Makoto Mizutani, Hidehiko Umezawa and Shigemi KURAMasU

Laboratory Animal Research Station, Nippon Institute for Biological Science, Kobuchizawa, Yamanashi wken 409-16

Blood typing in chickens has been studied by isoimmunized sera, and 12 systems, including the $B$ system known as the major histocompatibility complex, have been reported. Recently, the $B$ system has been analysed in detail by using inbred strains and the similarity of the $B$ system to the $\mathrm{H}-2$ locus in mice and the HLA locus in man has been reported. Producing a large quantity of specific reagents by isoimmunization for the typing of chicken red blood cells is a troublesome problem, since it is difficult to standardize the reagents from many laboratories. Lectins (PHA), viral hemagglutinins (VHA) and tissue hemagglutinins (THA) are useful as sources of reagents used to differentiate the red blood cells of individual chickens. In this study, extracts prepared from 159 different plants, including 44 species of Leguminosae, were tested for their agglutinabilities and hemolytic activities against the red blood cells obtained from 10 chickens, all Black Minorca, White Leghorn, Fayoumi or New Hampshire. Based on the results obtained, these extracts could be classified into six groups: Group I, 78 extracts which neither agglutinated nor hemolyzed the red blood cells of all the chickens tested; Group II, 40 extracts which agglutinated but did not hemolyze the red blood cells of all the chickens tested: Group III, 11 extracts which did not agglutinate but did hemolyze the red blood cells of all the chickens tested; Group IV, 3 extracts which both agglutinated and hemolyzed the red blood cells of all the chickens tested; Group V, 24 extracts which agglutinated the red blood cells of some chickens, but did not agglutinate the remainder and did not hemolyze the red blood cells of all the chickens tested; Group VI, 3 extracts which agglutinated the red blood cells of some chickens, but did not agglutinate the remainder and did hemolyze the red blood cells of all the chickens tested. Lectins in Group V and VI could be divided into four groups from their agglutinabilities: a) Lectins which agglutinated the red blood cells of certain chickens, regardless of sex. b) Lectins which reacted with $\mathrm{Hi}(\mathrm{Ph})$ agglutinogen only in certain laying females ( $\mathrm{Hi}$ positive), but did not react with the red blood cells from any males or non-laying females. c) Lectins which had the properties of both groups a and b: agglutination was observed only with the red blood cells from certain young chickens, regardless of sex. Also, in certain laying females, agglutinability was changed by the appearance of a new agglutinogen which was different from Hi agglutinogen. Lectins prepared from potato and tulip belonged to this group. d) Lectins which reacted with an agglutinogen which appeared in certain laying hens, and was different from both $\mathrm{Hi}$ and the agglutinogens belonging to group c. Lectin prepared from Allium tuberosum belonged to this group.

Jpn. J. Zootech. Sci., 54 (9): 525-534, 1983 